Egypt. Acad. J. Biolog. Sci., 10(1): 27- 45 (2018)

Egyptian Academic Journal of Biological Sciences

D. Histology \& Histochemistry

$2090-0775$

www.eajbs.eg.net

\title{
The Caryophylleadae cestodes, Wenyonia spp Woodland, 1923 Bioaccumulates High Quantities of A Specific PCBs Congener in the Fish Host, Synodontis clarias (Linnaeus, 1758), with Histopathological Alterations as Biomarker Response
}

\author{
${ }^{1}$ Akinsanya Bamidele, ${ }^{2}$ Kuton Minasu Pentho ${ }^{2}$ Arowoshafe Rasaq Adekunle, \\ ${ }^{2}$ Lawal Are Aderonke $O$ and ${ }^{2}$ Akhiromen Dorathy Iniobong \\ 1- Department of Zoology, University of Lagos \\ 2- Department of Marine Sciences, University of Lagos \\ E.Mail.: bamidele992@gmail.com
}

\begin{tabular}{l} 
ARTICLE INFO \\
Article History \\
Received: $5 / 6 / 2018$ \\
Accepted: $22 / 9 / 2018$ \\
\hline Keywords: \\
PCB \\
Parasites \\
Bioaccumulation \\
Sediment \\
Synodontis clarias
\end{tabular}

\section{INTRODUCTION}

\section{ABSTRACT}

One hundred and fifty samples of Synodontis clarias were collected,and subjected to parasitologic examination. They were analyzed from three stations of the sampling site (Epe axis of Lekki Lagoon). Out of the total number of specimens examined from the three stations, $56(37.33 \%)$ were infected. The total infected individuals from the three stations had 30 (20.0\%) males and $26(17.33 \%)$ females while the non-infected individuals for all the stations had $64(42.67 \%)$ males and females. Also, in this study, Synodontis clarias were infected with two (2) species of parasites the Cestodes (Wenyonia spp) and Nematode (Raphidascaroides spp) which is common among family Mockokidae. The concentration of Polychlorinated biphenyl in the fish tissue, parasite, sediment and water collected from the sampling site were also analyzed . The PCB congeners 8 , $18,28,44,77,81,123,153,156$ detected in the water and sediment sample of all the 209 PCB congeners were also reported. The findings presented in the study showed more of the lower chlorinated PCB congeners in the water sample than in the sediment, Synodontis clarias and parasite sample from the three stations in the Epe axis of Lekki Lagoon. The concentration of PCB congeners in the parasite was high in Oribo and Ikosi (549.53 ppb and 569.95ppb) sampling station while it is low in Imode (57.77ppb) station. There was high quantity of PCB 81 found in the parasite but not found in the fish host.The fish samples collected from Oribo had the high concentration of congeners $28,18,44$, and 52 among other detected, while fish samples collected from station Imode had the high concentration of $44,18,8$ and 28 and the fish samples collected from station Ikosi also had the high concentration of PCB 44, 18, 8 and 123 respectively. However, the concentration of PCBs level found in the fish tissue was above W.H.O limits of 200 part per billion (ppb) in Oribo and Ikosi ((607.42ppb and 325.43ppb) sampling station while the concentration was below in Imode (188.61 ppb) sampling station and hence the Synodontis clarias in Oribo and Ikosi is not safe and edible for consumption.

Persistent organic pollutants can not be degraded easily through biological, chemical and light processes (El- Shahawi et al., 2010). PCBs are a group of synthetic organic chemicals that contain 209 congeneers.

These chemically related compounds vary in their physiochemical properties and toxicity (Beyer et al., 2002). Due to the affinity of PCBs to adsorb to suspended particulate material like sediment and biota and their hydrophobic behaviour, they can be found in nearly all water bodies and in all biota (Walker et al., 1997). The chemicals have being in use to assist man (Erickson et al., 1997). They are also important as a fluid in transformers and capacitors. PCBs was no longer in use in the 
United States as a result of their consequences on humans (ASTDR, 2001). Man and animal can be exposed to PCBs with serious effects. The chemicals that have entered into sedimentsare not readily available to organisms that have been exposed to them. (EPA 1994). These chemicals enter into man when foods contaminated with them are eaten. (Fitzgerald et al., 1996). This happened simply because the chemical has been accumulating in the diet of man.

In addition, ingestion of PCBs that have accumulated in fish is a way of introduction of the chemicals in the human surroundings (EPA 2005).

As a result of nondegradable nature of the chemical, they bio-accumulate in the human surroundings (Erickson 1997). The process of biomagnification of PCBs is as a result of higher trophic level organisms having large contaminant within their bodies than.(Danuta et al., 1997). PCBs may enter water bodies and tend to accumulate in the sediments (Ashley and Baker 1999).PCBs are also found in the in the fatty tissues of fish and when consumed by humans may represent a major pathway of exposure (Birmingham et al., 1989).There is a high levels of exposure to PCBs with attendant effects (WHO 1992).

Parasites have a high level role in the ecosystem which are being neglected by scientists (Lafferty et al., 2008). Fish parasites was used as biological indicators with methodologies related to fisheries(McKenzie 2002). Pollution is an added stress to hosts which made the hosts to be vulnerable to parasitic diseases (Arkoosh et al., 1998). There is a relationship between parasitism and pollution which compel the use of parasites to evaluate environmental stressors (Sures, 2006).Parasites also influence the hosts' response. (Sures and Radszuweit 2007).

Fish are specific indicators of different levels of contaminants bioaccumulation depending on habitat or food chain position (Scaps, 2002). Some parasites can not tolerate environmental chemicals while others tend to increase in number in pollutant conditions (Sures, 2004). Parasitic infections in fish is related to the degree of immunity in the hosts (Szefer et al., 1998). Parasites exhibit some pathological consequences on their hosts such as depletion of host energy,behaviours alterations, morphological abnormalities, fecundity reduction, growth retardation and mortalities (Marcogliese, 2004).

There has been several published report on fish parasites as the potential indicators of environmental contaminants (Sures et al, 1999). Biomonitoring is a unique field that uses several biological groups such as invertebrates and fish as bioindicators (Rosenberg and Resh, 1993). This research therefore emphasises biological monitoring in lekki lagoon due to anthropogenic activities.

\section{MATERIALS AND METHODS}

Epe axis of lekki Lagoon is situated between latitudes $3050^{\prime}-4010^{\prime} \mathrm{N}$ and longitudes 5030'-5040'E. There are so many plants and fishes as reported by Akinsanya (2007).Map of the lagoon is shown in Fig 1. Three stations were randomly selected with their geographical locations shown in Table 1. 


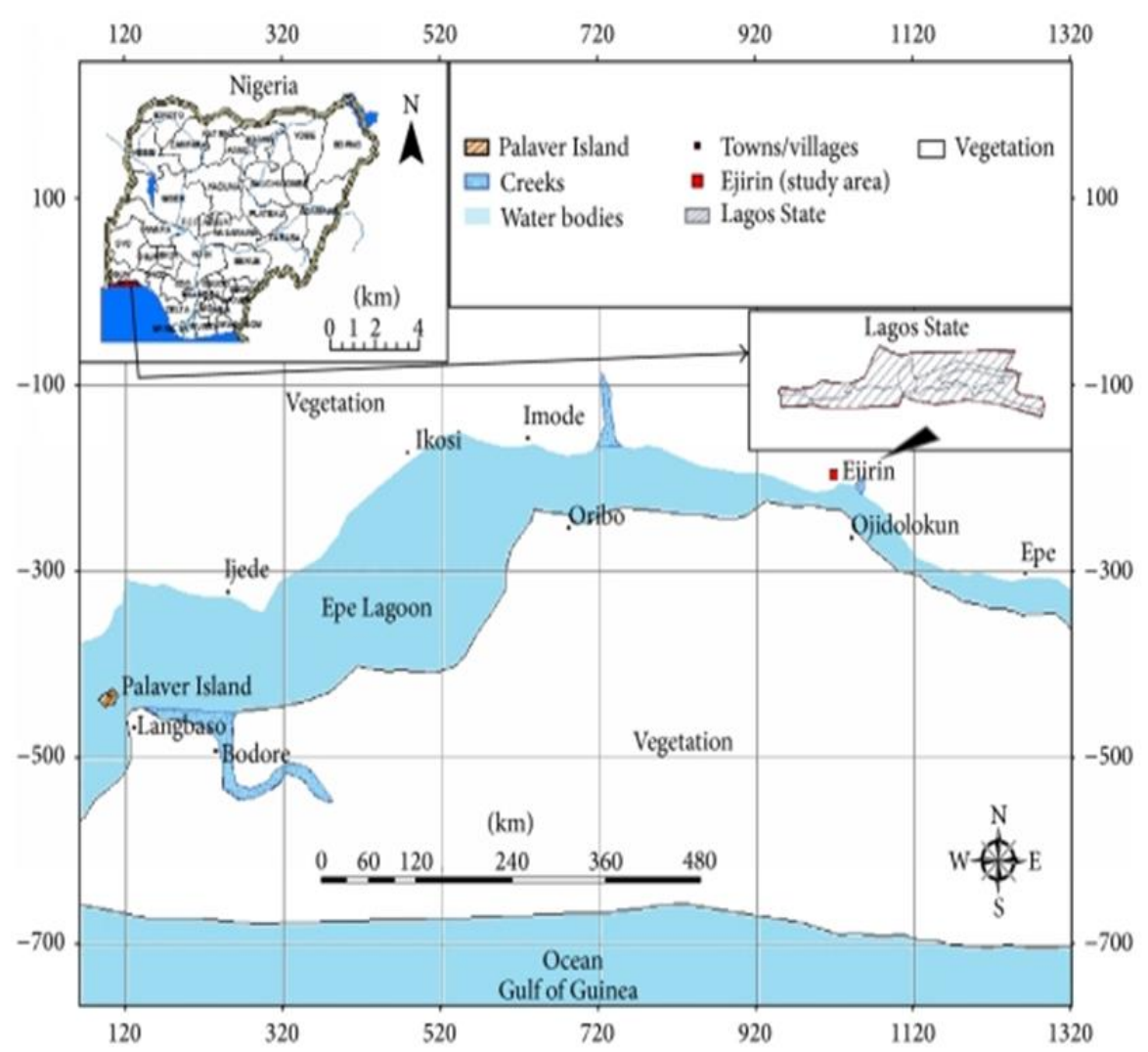

Fig. 1: Map of Epe Lagoon

Table 1: Showing geographical locations of sampling sites

\begin{tabular}{|l|l|l|l|}
\hline S/N & Latitude & Longitude & Station \\
\hline 1. & $6034^{\prime} 50.11 "$ & $3059 ' 34.11^{\prime \prime}$ & ORIBO \\
\hline 2. & $6034^{\prime} 56.17^{\prime \prime}$ & $3059 ' 26.92 ”$ & IKOSI \\
\hline 3. & $6034^{\prime} 52.34 ”$ & $3059 ' 14.32 ”$ & IMODE \\
\hline
\end{tabular}

\section{Collection of Samples:}

Specimens of Synodontis clarias were randomly collected at the sample locations. These were purchased at Oluwo Market from local fishmongers who are based at the Epe jetty, Lagos, Nigeria. A total of 150 (length ranged from $20-36 \mathrm{~cm}$ and weight ranged from 88.8 - 220 g) Synodontis clarias specimens were collected on six trips over a period of 3 months from July, 2016 to September, 2016. Most of the specimens were purchased while still alive. The sex and maturity of the collected specimens were determined by gross examination of the gonad. The weights of the fish were recorded using a weighing balance (Camry, EK5055), standard lengths and total lengths of the fishes also were recorded using a measuring board.

\section{Collection of water samples:}

From the three stations, water samples were collected on one of the field trips. Water samples were collected using a five liters container which was firstly cleaned with the surface water at each site. The collected samples were stored in the refrigerator for further analysis. Samples were collected for analysis of physiochemical parameters.

Water collected from Epe lagoon was used to analyse the following physico-chemical parameters: hydrogen ion concentration $(\mathrm{pH})$, temperature, conductivity, salinity, dissolved oxygen, 
total suspended solids and total dissolved solids using standard methods.

\section{Hydrogen Ion Concentration (pH)::}

This is simply to measure the hydrogen ion activity in the water .The $\mathrm{pH}$ was determined in situ with the aid of a pH meter.

\section{Temperature:}

The temperature was measured using a thermometer. It was done by lowering the thermometer so the tip is a few inches below the water surface. The thermometer time came to equilibrium and the values were read off and recorded.

\section{Conductivity:}

This is to determine the conductivity of a solution . Water with absolutely no impurities (which is rare) is a poor conductor of electricity. In the real sense, the impurities in water increase its conductivity. The conductivity was measured using the Horiba water quality checker, model U-10. The water sample was put in the sample cup and coupled with the probe, and readings were recorded from the meter.

Salinity:

The salinity was done in-situ with the aid of refractometer. One drop of the water was placed on the prime of the meter of the refractometer and the meter was adjusted to $0 \%$ marks and viewed through the eye piece. The daylight plate was closed and the salinity was read on the scale.

\section{Dissolved Oxygen:}

The dissolved oxygen level was measured in-situ using a DO meter. The probe was placed in the water sample and the reading was recorded from the meter. The trimetric method was used for the determination of dissolved oxygen demand. The BOD bottle was submerged with the cap in the sample water. The cap was employed and the BOD bottle was filled with water. The BOD bottle was covered while it was still under water. The BOD bottle was removed and it was checked for air bubbles. Immediately 8 drops of alkaline Potassium Iodide azide solution was added. The solution in the bottle was mixed by inverting it several times. The precipitate was then allowed to settle. 1 gram spoon was used to add one level measure of $\mathrm{H}_{2} \mathrm{SO}_{4}$ powder. The mixture was gently inverted to mix the contents until the reagents totally dissolved.

The titration bottle was filled to $20 \mathrm{ml}$ line with the sample and 8 drops of starch indicator solution were added. The sample turned blue, this was then titrated against a standard solution of sodium thiosulphate until the blue coloration disappeared.

$$
\mathrm{DO}(\mathrm{mg} / \mathrm{l})=\quad \frac{16,000 \times \mathrm{M} \mathrm{x} \mathrm{V}}{\left[\frac{\mathrm{V}_{2}}{\mathrm{~V}_{1}}\right][\mathrm{V} 1-\mathrm{V} 2]}
$$

$\mathrm{M}=$ Molarity of Thiosulphate $\mathrm{V}=$ Volume of Thiosulphate used for titration $\mathrm{V}_{1}=$ Volume of bottle with stopper in place $\mathrm{V}_{2}=$ Volume of aliquot taken for titration

\section{Total Suspended Solids:}

A portion of the water sample was measured and filtered using pre-weighed what-man filter paper. The filter paper with the residue was dried for 1 hour at $105^{\circ} \mathrm{C}$ in an oven. The filter paper with then residue was then cooled and weighed. The amount of suspended solids was calculated using the formula: 


$$
\begin{aligned}
& \mathrm{SS}=\mathrm{R}-\mathrm{F} \\
& \mathrm{SS}=\text { Suspended Solids } \\
& \mathrm{R}=\text { Weight of filter paper and residue } \\
& \mathrm{F}=\text { Weight of the filter paper }
\end{aligned}
$$

Total Dissolved Solids:

One hundred cubic centimeters $\left(100 \mathrm{~cm}^{3}\right)$ of the filtered sample was measured. This was transferred into a weighed evaporating dish. This was

Total dissolved solids (TDS) were calculated using:

$$
\text { Total dissolved solids }(\mathrm{mg} / \mathrm{l})=\frac{\mathrm{R}-\mathrm{D} \times 1000}{\text { Volume of filtered sample }}
$$

$\mathrm{R}=$ weight of evaporating dish \& residue

$\mathrm{D}=$ weight of the evaporating dish.

\section{Laboratory Procedures:}

\section{Determination of Phosphate:}

The surface water Phosphatephosphorus was determined using the ascorbic acid method. A mixture was prepared by mixing $1 \%$ ammonium molybdate in $2 \mathrm{M} \mathrm{H}_{2} \mathrm{SO}_{4}$ and Hydrazine

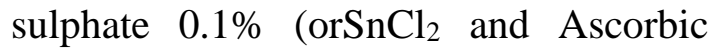
acid immediately before use). The resulting solution $\mathrm{PO}_{4} / \mathrm{mg} / \mathrm{ml}$ of 4.39 $\mathrm{KH}_{2} \mathrm{PO}_{2}$ (dried at $110^{\circ} \mathrm{C}$ ) was dissolved in distilled water. $1 \mathrm{ml} \mathrm{CHCl}_{3}$ was added and further diluted to one liter of distilled water. 10 to $25 \mathrm{ml}$ of the sample was acidified with nitric acid and $25 \mathrm{ml}$ of the reagent was added. The absorbance was read off using 780nm.

\section{Determination of Nitrates:}

Surface water Nitrate-nitrogen was determined gravimetrically, $20.0 \mathrm{ml}$ of the water sample was added to $1 \mathrm{ml}$ of fresh prepared $0.3 \%$ Sodium salicylate. The mixture was then evaporated in a bath and thereafter left to cool. On cooling, $2 \mathrm{ml}$ sulphuric acid was added for $10 \mathrm{~min}$, the solution was then washed with $25 \mathrm{ml}$ of distilled water into a calorimetric cylinder. $7 \mathrm{ml}$ of alkaline reagent $(30 \%$ $\mathrm{NaOH}$ and $60 \%$ Rochelle salt) was added. Next, the solution was made up to $50 \mathrm{ml}$ by adding distilled water. The yellow colour developed was matched with prepared standards using a calorimeter at $420 \mathrm{~nm}$. The nitrate content was recorded in $\mathrm{mg} / \mathrm{l}$.

\section{Biochemical Oxygen Demand (BOD):}

This is a measure of the amount of oxygen that is removed from water sample due to natural biological assimilation or degradation of organic compounds by the organisms present, especially bacteria. The Biochemical Oxygen Demand for the water samples from the study area was determined to take the difference between the DO content of the samples on the day of sample collection and then 5 days after the samples were collected. The water samples were incubated at $20^{\circ} \mathrm{C}$ for five days. Measurement of the 5-day DO was carried out using the same Horiba water checker (Model U-10) used to measure the DO during the sampling period.

\section{Sediment Collection and Analysis:}

Sediments were collected with the aid of Van Veen grab at $4^{\circ} \mathrm{C}$ in an icebox and transported to the laboratory. The samples were separated and air dried in a laboratory. It was homogenized and sieved to eliminate particulates of sediments samples which were then digested as follows: $5 \mathrm{~g}$ of the powdered sediment samples were weighed into a $100 \mathrm{ml}$ beaker. $15 \mathrm{ml}$ of the freshly prepared mixture of $\mathrm{HNO}_{3} / \mathrm{H}_{2} \mathrm{O}_{2}$ ratio 1:1 were added to each sample and covered with washed glass. It was 
allowed to stand for 30 minutes during which the initial reaction subsided. Digestion was carried out on a hot plate whose temperature was allowed to rise gradually until it reached a maximum temperature of $160^{\circ} \mathrm{C}$ in a fume cupboard. Heating was continued for about 2 hours, reducing the volume in the beaker to about 2-5 $\mathrm{ml}$. The beaker were allowed to cool while the content was transferred with what man filtration into a $50 \mathrm{ml}$ volumetric flask and made up to mark with distilled water (FAO/SIDA, 2003).

Examination and Method of Analysis of Fish Samples:

Collection of Internal Organs of the fish samples:

A total of one hundred and fifty specimens of freshly obtained Synodontis clarias from Epe axis of Lekki Lagoon were randomly collected bimonthly during the wet season (July - September) at three different locations along the Epe axis of Lekki Lagoon, Epe Lagos, Nigeria. The fish were immediately preserved in an ice-chest with ice-blocks prior to laboratory analysis. The collected fish samples were arranged on a table. Each fish was slit open using scissor through the urogenital opening. Specific internal organs (Gills, liver, and gastrointestinal tract) were then carefully extracted and placed in Petri dishes filled with $0.09 \%$ saline.

\section{Examination of the Gastrointestinal} Tract:

Examination of parasites presents within the intestinal tract was carried out using the techniques of Akinsanya et al. (2007). The Petri dishes containing the internal organ were examined using a hand lens. Afterward, the intestines were carefully teased open from the anterior to the posterior end (from the rectum through to the esophagus region) to aid parasite emergence. The emergence of the parasite was carefully observed through its movement in the saline solution. The recovered parasites were fixed in $70 \%$ alcohol, counted and recorded.

\section{Preservation of Organs and Parasites:}

The organs were stored in labelled universal bottles with $0.09 \%$ saline, then transported to the laboratory for further analysis

Recovered parasites were fixed in $70 \%$ alcohol in differently labeled specimen bottles.

\section{Histological Assessment of Fish Samples:}

The selected target organ, the intestines from both infected and uninfected intestines were dissected for histological preparation and processed under standard histological procedure.

\section{Analysis of PCBS:}

All chemicals and reagents were of analytical grade and of highest purity possible. LC grade dichloromethane and n-hexane used for the extraction and clean up were obtained from Fisher Scientific. The silica gel used in clean up was supplied by BDH Laboratories. The acetone and anhydrous sodium sulphate used in this study were also obtained from BDH Laboratories. A mixture of 8 PCB congeners (namely PCBs 28, 52, 107, 105, 118, 153, 156 and 180) was obtained from Sigma Aldrich.

\section{Extraction:}

Prior to extraction, the fish specimens were dissected and the muscle tissue removed. $10 \mathrm{~g}$ of muscle tissue was ground with anhydrous sodium sulphate until completely dry homogenate was obtained (Anyakora et al., 2005). Extraction was carried out with dichloromethane in a cold extraction mode (Anyakora et al., 2004). After the extraction, the extracting solvent was evaporated using a rotary evaporator and the mass of the extractable fat determined by gravimetry.

\section{Sample Clean Up:}

The isolation of PCBs from the lipid matrix was done by solid phase extraction in a normal phase mode. Activated silica gel was loaded into a 
glass chromatographic column $(20 \mathrm{~mm}$, height $400 \mathrm{~mm}$ ) and conditioned with dichloromethane. The extractable fats from the samples were dissolved in $5 \mathrm{ml}$ n-hexane and loaded on to the column and eluted with about $60 \mathrm{ml} \mathrm{n}$-hexane. The effluents were then concentrated using a rotary evaporator and under a gentle stream of pure nitrogen. The samples were thereafter dissolved in $1 \mathrm{ml}$ acetone and ready for $\mathrm{GC}$ analysis.

\section{Gas Chromatography:}

Analyses were performed with Perkin model 5890 gas chromatograph equipped with $\mathrm{Ni} 63$ electron capture detector. A low polar HP-5 column of 30 m length, $0.32 \mathrm{~mm}$ and $0.25 \mathrm{~mm}$ film thickness was used. Nitrogen was used as a carrier gas at a flow rate of flow rate 40 $\mathrm{ml} / \mathrm{s}$. Data were processed using an HP 3396 integrator. The operating parameters were as follows: injector temperature set at 250 and $300^{\circ} \mathrm{C}$ for the detector, the oven temperature was programmed at $150^{\circ} \mathrm{C}$ initially $(5 \mathrm{~min}$ hold) and increased to 300 at $4^{\circ} \mathrm{C} / \mathrm{min}$ to give the analysis period of $34 \mathrm{~min}$.

\section{Identification and Quantification:}

PCB congeners in the fish were identified by retention time match with those of the standards. The standard mixture contains PCBs 28, 52, 107, $105,118,153,156$ and 180. Hence only these congeners were identified and determined in the fish samples during this study, quantification was done based on area count match with those of known concentration of the standards. Parasitic prevalence and mean intensity were calculated using the formulae according to Ezewanji, et al., (2005) as thus:

\section{Calculation of Bioaccumulation Factor (BAF):}

Bioaccumulation is the increase in concentration of the test substance in or on an organism (specified tissues thereof) relative to the concentration of test

\section{$\frac{\text { Number of fish infected }}{\text { Number of } f \text { ish examined }} \times 100$ \\ Total number of parasite \\ Number of fish infected \\ Number of collected parasites \\ Number of infected fish \\ Number of collected parasites \\ Number of fish examined}

substance in the surrounding medium, the biota to soil accumulation factor (BSAF) and bio-concentration factor (BCF) were determined as ratio of PCBs in the fish to that in the soil and water samples as follows:

$\mathrm{BSAF}=\frac{\text { Concentration of PCBs in animal tissue }}{\text { Concentration of PCBs in soil sample }}$

$\mathrm{BCF}=$ Concentration of PCBs in animal tissue Concentration of PCBs in water sample

\section{Statistical Analysis:}

Data generated from the investigations was entered into Microsoft excel spread sheet (2013) and later subjected to two-way analysis of variance (ANOVA) (SPSS Version 20 software).

\section{RESULTS}

Physiochemical Parameters in three stations at Epe Lagoon Lagos, Nigeria

Table 2 presents the physiochemical parameters of the water sample obtained from the three different stations at the study location. A slight variance in the parameters recorded is 
observed within the stations. The mean value recorded for the parameters include: $\mathrm{pH}$ of $6.6 \pm 0.1,6.4 \pm 0.3,6.5 \pm 0.1$, dissolved oxygen; $4.5 \pm 0.4, \quad 3.50 \pm 0.3$, $3.2 \pm 0.2 \mathrm{mg} / \mathrm{l}$, total suspended solids; $11 \pm 5.5, \quad 7.1 \pm 2.6, \quad 9 \pm 1.5 \mathrm{~g} / \mathrm{l}, \quad$ total dissolved solids; $106.3 \pm 8.4,113.9 \pm 6.3$,
$110.1 \pm 5.6 \mathrm{~g} / \mathrm{l}, \quad$ conductivity; $152.7 \pm 0.5$, 172.3 $\pm 2.6, \quad 193.3 \pm 3, \quad \mu \mathrm{S} / \mathrm{cm}, \quad$ salinity; $4 \pm 0.5, \quad 5 \pm 0.3, \quad 4.5 \pm 0.5 \mathrm{ppt}$, turbidity; $10.3 \pm 3.5,7.7 \pm 3.2$, and $7.7 \pm 2.5 \mathrm{NTU}$, for the three stations (ORIBO, IMODE, IKOSI) respectively.

Table 2: Showing the Physicochemical Parameters of the Sampling Locations

\begin{tabular}{|l|l|l|l|l|}
\hline Parameters & Oribo (mean) & Imode (mean) & Ikosi (mean) & Fepa Limit \\
\hline Temperature $\left({ }^{\circ} \mathrm{C}\right)$ & $26.5 \pm 0.5$ & $25.8 \pm 0.3$ & $25.2 \pm 0.7$ & $<40$ \\
\hline $\mathrm{pH}$ & $6.6 \pm 0.1$ & $6.4 \pm 0.3$ & $6.5 \pm 0.1$ & $6-9$ \\
\hline Dissolved Oxygen $(\mathrm{mg} / \mathrm{L})$ & $4.5 \pm 0.4$ & $3.5 \pm 0.2$ & $3.2 \pm 0.3$ & $>5.0$ \\
\hline Total Suspended Solids $(\mathrm{g} / \mathrm{L})$ & $11 \pm 5.5$ & $7.1 \pm 2.6$ & $9 \pm 1.5$ & $\mathrm{NA}$ \\
\hline Total Dissolved Solids $(\mathrm{g} / \mathrm{L})$ & $106.3 \pm 8.4$ & $113.9 \pm 6.3$ & $110.1 \pm 5.6$ & 2000 \\
\hline Conductivity $(\mu \mathrm{S} / \mathrm{cm})$ & $152.7 \pm 0.5$ & $172.3 \pm 2.6$ & $193.3 \pm 3$ & $\mathrm{NA}$ \\
\hline Salinity $(\mathrm{ppt})$ & $4 \pm 0.5$ & $5 \pm 0.3$ & $4.5 \pm 0.5$ & $\mathrm{NA}$ \\
\hline Turbidity $(\mathrm{NTU})$ & $10.3 \pm 3.5$ & $7.7 \pm 3.2$ & $7.7 \pm 2.5$ & 10 \\
\hline
\end{tabular}

Prevalence of Intestinal Helminth Parasite of Synodontis clarias in Lekki Lagoon, Lagos:

Table 3: Shows the prevalence of intestinal helminth parasite of Synodontis clarias in Lekki Lagoon, Lagos. Out of the 120 fishes collected, 45 were females and 75 were males; 45 fishes were infected $(37.5 \%)$ and 75 fishes were not infected $(62.5 \%)$. The Chi-square $\left(\mathrm{x}^{2}(3)\right)$ for the distribution is $14.79^{* *} \mathrm{p}<0.001$. Among the sexes, 21 females were infected $(46.67 \%)$ and 24 were not infected $(53.33 \%), 24$ males were infected $(32 \%)$ and 51 males were not infected (68\%). The parasites found in the intestine of the infected fish were cestodes (Wenyonia spp) and nematoda (Raphidascaroides spp) and are shown in plate $1 \mathrm{a}$ to $2 \mathrm{~b}$. Plates $1 \mathrm{a}$ and $1 \mathrm{~b}$ show the cephalic and caudal regions of the Wenyonia spp found in the infected intestine while plates $2 \mathrm{a}$ and $2 \mathrm{~b}$ show the cepahalic and caudal regions of the Raphidiaroides spp.

Table 3: Prevalence of Intestinal Helminth Parasite of Synodontis clarias in Lekki Lagoon Lagos

\begin{tabular}{|l|l|l|l|}
\hline Sex/Infection & Number examined & Infected & Non-Infected \\
\hline Female & $56(37.5 \%)$ & $26(17.33 \%)$ & $30(20.00 \%)$ \\
Male & $94(62.5 \%)$ & $30(20.00 \%)$ & $64(42.67 \%)$ \\
\hline Combined & $150(100 \%)$ & $56(37.33 \%)$ & $94(62.67 \%)$ \\
\hline
\end{tabular}

Morphometrics and Condition Factor of Synodontis Clarias in Lekki Lagoon, Lagos:

Table 4: Shows the morphometrics and condition factor of Synodontis clarias in Epe axis of Lekki Lagoon, Lagos. Standard length of mean is $14.34 \pm 1.19, \mathrm{p}<0.01$, with minimum and maximum value of $11.00-20.00(\mathrm{~cm})$. Total length with mean, 20.35 \pm 1.81 , $\mathrm{p}<0.01$ with minimum and maximum value of $15.00-26.00(\mathrm{~cm})$. Weight with mean \pm SD, $\quad 64.72 \pm 11.47, \quad \mathrm{p}<0.01$ with minimum and maximum value of 28.50$105.50(\mathrm{~g})$. Liver weight with mean \pm SD, $1.10 \pm 0.48, \mathrm{p}<0.01$ with minimum and maximum value of $0.30-3.00(\mathrm{~g})$. Gonad weight with mean $\pm S D, 2.02 \pm 3.49$, $\mathrm{p}<0.01$, with minimum and maximum value of $0.00-20.00(\mathrm{~g})$. The number of the parasite with mean $\pm \mathrm{SD}, 2.12 \pm 4.48$, $\mathrm{p}<0.01$ with minimum and maximum value of $0.00-20.00$. Condition factor with mean $\pm S D, 2.21 \pm 0.36, p<0.01$ with minimum and maximum value of 1.00 3.60 . 
Table 4: Morphometrics and condition factor of Synodontis clarias in Lekki Lagoon, Lagos, Nigeria.

\begin{tabular}{|l|l|l|l|l|}
\hline Parameters & N & Mean & SD & Min-Max \\
\hline Standard length $(\mathbf{c m})$ & 150 & $14.34 * *$ & 1.19 & $11.00-20.00$ \\
\hline Total length $(\mathbf{c m})$ & 150 & $20.35 * *$ & 1.81 & $15.00-26.00$ \\
\hline Weight $(\mathbf{g})$ & 150 & $64.72 * *$ & 11.47 & $28.50-105.50$ \\
\hline Liver weight $(\mathbf{g})$ & 150 & $1.10^{* *}$ & 0.48 & $0.30-3.00$ \\
\hline Gonad weight $\mathbf{( g )}$ & 150 & $2.02 * *$ & 3.49 & $0.00-14.00$ \\
\hline No of parasite & 150 & $2.12^{* *}$ & 4.48 & $0.00-20.00$ \\
\hline Condition factor & 150 & $2.21 * *$ & 0.36 & $1.00-3.60$ \\
\hline
\end{tabular}

** Mean significant at level 0.01

*Mean significant at level 0.05

Length-Weight Relationship in $p<0.001, \beta=0.704)$, the exponential Synodontis Clarias in Lekki Lagoon, model coefficient as $\left(\mathrm{R}^{2}=0.492\right.$, Lagos using Nine Regression Models: $\quad \mathrm{p}<0.001, \beta=0.704)$, and the logistic

Table 5 shows the correlation model coefficient as $\left(\mathrm{R}^{2}=0.492\right.$, coefficients of the linear model $\left(\mathrm{R}^{2}=\mathrm{p}<0.001, \quad \beta=0.495\right)$. The logistic, 0.453, $\mathrm{p}<0.001, \beta=0.675)$, and the exponential and growth models have the logarithm coefficient $\left(\mathrm{R}^{2}=0.470\right.$, same correlation coefficient $(\mathrm{R}=0.704$, $\mathrm{p}<0.001, \quad \beta=0.688)$, the quadratic $\mathrm{p}<0.001)$; and also the quadratic and coefficient as $\left(\mathrm{R}^{2}=0.465, \mathrm{p}<0.001, \beta=\right.$ cubic models correlation coefficient 1.620), Cubic coefficient as $\left(\mathrm{R}^{2}=0.465\right.$, being the same $(\mathrm{R}=0.688, \mathrm{p}<0.001)$; $\mathrm{p}<0.001, \quad \beta=1.620)$, compound with the highest being the power model coefficient as $\left(\mathrm{R}^{2}=0.492, \mathrm{p}<0.001, \beta=(\mathrm{R}=0.721, \mathrm{p}<0.001)\right.$; and the linear 2.022), the power model coefficient as model being the least $(\mathrm{R}=$ $\left(\mathrm{R}^{2}=0.517, \mathrm{p}<0.001, \beta=0.721\right)$, growth $0.675, \mathrm{p}<0.001)$. model coefficient as $\left(\mathrm{R}^{2}=0.492\right.$,

Table 5: Length-Weight relationship in Synodontis clarias using nine regression models

\begin{tabular}{|l|l|l|l|}
\hline Models & $\mathbf{R}$ & $\mathbf{R}^{\mathbf{2}}$ & $\mathbf{B}$ \\
\hline Linear & $0.695^{* *}$ & $0.479^{* *}$ & 0.695 \\
\hline Logarithm & $0.711^{* *}$ & $0.502^{* *}$ & 0.711 \\
\hline Quadratic & $0.731^{* *}$ & $0.526^{* *}$ & 3.374 \\
\hline Cubic & $0.731^{* *}$ & $0.526^{* *}$ & 3.374 \\
\hline Compound & $0.691^{* *}$ & $0.473^{* *}$ & 1.996 \\
\hline Power & $0.714^{* *}$ & $0.506^{* *}$ & 0.714 \\
\hline Growth & $0.691^{* *}$ & $0.473^{* *}$ & 0.691 \\
\hline Exponential & $0.691^{* *}$ & $0.473^{* *}$ & 0.691 \\
\hline Logistic & $0.691 * *$ & $0.473^{* *}$ & 0.501 \\
\hline
\end{tabular}

Histopathological Alterations Showing A Degree of Changes in The Intestines and Gills of Synodontis clarias in Epe Lagoon, Lagos:

The microscopic study of the infected intestine and gill recovered from the fish host revealed different pathological effects. These effects are shown in plate 1 .
The infected intestine showed severe congestion of the submucosa. The villi structure and the surface epithelial were moderately preserved while the gill showed vasolidation with blood congestion of primary filament, loss of filaments, curling of filaments and hyperplasia. 

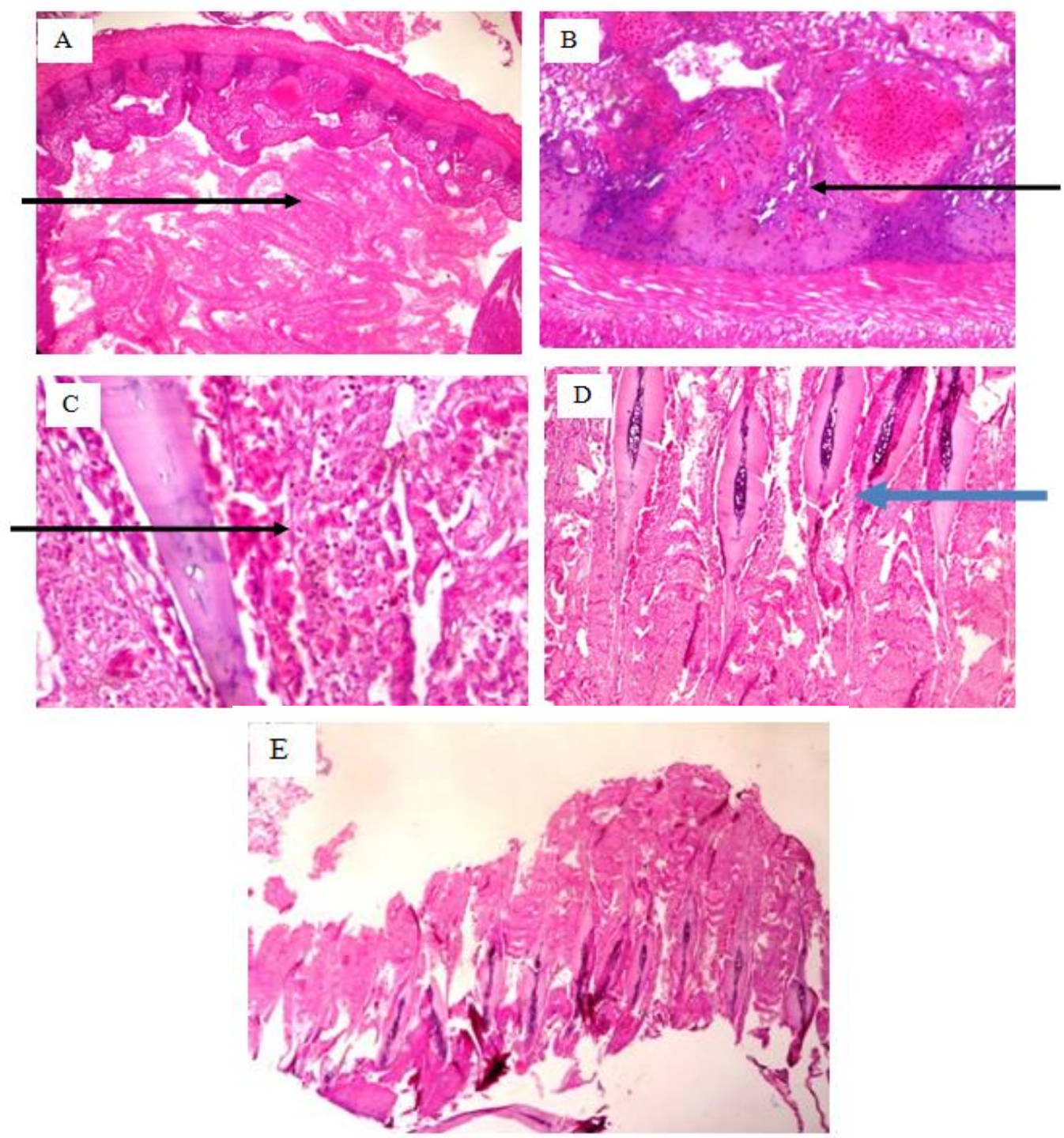

H\&E X400

PLATES: 1 (A): The villi structure and the surface epithelial were moderately preserved. (B) Photomicrographs of intestinal tissue show severe congestion of the submucosa (black arrow). (C) gill showing vasodilation with blood congestion of primary filament (black arrow). (D) Loss of filaments (blue arrow). (E) Curling of filaments and hyperplasia.

Mean Concentration of PCBS significantly impacting the aquatic Congeners in the Tissue of Synodontis ecosystem. (Table 6). There was no clarias across Stations (PPB):

The analysis of polychlorinated biphenyls in the tissue of Synodontis clarias from Epe axis of Lekki Lagoon showed that Between the three stations there was a significant difference (Anova, $\mathrm{P}>0.05$ ) in the congeners identified, possibly indicating that PCBs availability and concentrations were significant difference between congeners in Oribo and Ikosi but revealed that there was a significant difference between congeners in Imode. The trend of mean concentration ranged from 5.02 (PCB 77) to 265.73 (PCB 44) in Oribo, 5.08 (PCB $123)$ to 71.12 (PCB 44) in Imode and 0.00 (PCB 52) to 32.37 (PCB 18) in Ikosi sampling station. 
Table 6: Mean concentration of PCBs congeners in the tissue of Synodontis clarias across stations

\begin{tabular}{|c|c|c|c|c|c|c|c|c|c|}
\hline \multirow[b]{3}{*}{ CONGENER } & \multicolumn{6}{|c|}{ FISH } & \multirow{2}{*}{\multicolumn{3}{|c|}{ IKOSI }} \\
\hline & \multicolumn{3}{|c|}{ ORIBO } & \multicolumn{3}{|c|}{ IMODE } & & & \\
\hline & $\begin{array}{l}\text { MEAN } \\
(\mathrm{PPB})\end{array}$ & SD & MAX & $\begin{array}{l}\text { MEAN } \\
(\mathrm{PPB})\end{array}$ & SD & MAX & $\begin{array}{l}\text { MEAN } \\
(\mathrm{PPB})\end{array}$ & SD & MAX \\
\hline PCB 8 & 7.96 & 11.25 & 15.91 & 35.44 & 49.023 & 70.00 & 12.44 & 8.59 & 19.00 \\
\hline PCB 18 & 202.00 & 264.37 & 389.30 & 46.58 & 56.32 & 86.00 & 28.41 & 32.37 & 51.00 \\
\hline PCB 28 & 44.77 & 63.32 & 89.55 & 21.36 & 22.96 & 38.00 & ND & 0.00 & 0.00 \\
\hline PCB 44 & 265.73 & 20.956 & 280.56 & 71.12 & 100.58 & 142.00 & 36.54 & 20.45 & 51.00 \\
\hline PCB 52 & 68.22 & 5.76 & 72.29 & 3.36 & 4.75 & 7.00 & 0.00 & 0.00 & 0.00 \\
\hline PCB 60 & ND & 0.00 & 0.00 & ND & 0.00 & 0.00 & ND & 0.00 & 0.00 \\
\hline PCB 77 & 5.02 & 7.09 & 10.03 & 5.68 & 8.03 & 11.00 & 8.38 & 11.85 & 17.00 \\
\hline PCB 101 & 7.99 & 11.31 & 15.99 & ND & 0.00 & 0.00 & ND & 0.00 & 0.00 \\
\hline PCB 123 & 5.37 & 7.59 & 10.73 & 5.08 & 7.189 & 10.00 & 10.22 & 0.86 & 11.00 \\
\hline TOTAL PCBS & 343.33 & & & 223.42 & & & 95.99 & & \\
\hline
\end{tabular}

*total pcb refers to the total pcb observed in the fish at that station

$*$ concentrations are reported in wet weight* $(\mathrm{p}>0.05)$

*nd (not detected)

Mean Concentration of PCB higher than those in the fish, their values Congeners in Parasites of Synodontis ranged from 0.00-483.20 in Oribo, 7.40 clarias across Stations (PPB):

Parasites from the fish samples at the three different stations were taken for PCBs analysis and their mean concentration was calculated although to 20.70 in Imode and 0.00 to 546.30 in Ikosi. (Table 7). However, the concentration of PCBs congener PCB 81 was high at Oribo and Ikosi and is above W.H.O residual limit of 200ppb.

the PCBs congeners identified were

Table 7: Mean concentration of PCBs congeners in parasite of Synodontis clarias across three sampling stations

\begin{tabular}{|l|l|l|l|}
\hline CONGENERS & ORIBO & IMODE & IKOSI \\
\hline PCB 18 & 50.70 & 20.70 & 21.70 \\
\hline PCB 28 & 0 & 7.40 & 0 \\
\hline PCB 52 & 15.70 & 9.30 & 0 \\
\hline PCB 77 & 0 & 8.20 & 0 \\
\hline PCB 81 & 483.20 & 12.20 & 546.30 \\
\hline TOTAL & 549.60 & 57.80 & 568.00 \\
\hline
\end{tabular}

*total pcbs refers to the total pcbs observed in the fish at that station

*concerntrations are reported in wet weight* $(p>0.05)$

*nd (not detected)

\section{Mean Concentration of PCB congeners in Sediment Media Across Stations (PPB):}

Sediment samples were taken from the three different sampling stations at Epe axis of Lekki lagoon and were taken for analysis, ORIBO means concentration ranges from 0.00 to 371.40 , while that of IMODE range from 0.00 to 821.70 and IKOSI from 0.00 to 358.10 . This is shown in table 8 . 
Table 8: Mean concentration of PCBs congeners in sediment across stations

\begin{tabular}{|l|l|l|l|}
\hline CONGENERS & ORIBO(PPB) & IMODE (PPB) & IKOSI (PPB) \\
\hline PCB 8 & 6.10 & 0 & 3.2 \\
\hline PCB 18 & 11.90 & 8.10 & 0 \\
\hline PCB 77 & 14.20 & 14.70 & 14.20 \\
\hline PCB 81 & 371.40 & 821.70 & 358.10 \\
\hline PCB 101 & 0 & 0 & 20.10 \\
\hline PCB 123 & 11.20 & 10.20 & 9.80 \\
\hline PCB 153 & 0 & 6.00 & 0 \\
\hline TOTAL & 414.90 & 860.70 & 405.40 \\
\hline
\end{tabular}

Mean Concentration of PCB had 3.1556 and 3.3071, the reason for Congeners in Water across three Imode high content may be due to the Stations (PPB):

Water samples were taken for analysis and across the three stations, Imode had the highest PCBs content with a total of 5.9608, while Oribo and Ikosi fact that it is just close to fresh water source when contaminants from anthropogenic activities enters the lagoon. (Table 9).

Table 9: Mean concentration of PCBs congeners in water three sampling across stations

\begin{tabular}{|l|l|l|l|}
\hline CONGENERS & ORIBO(PPB) & IMODE (PPB) & IKOSI (PPB) \\
\hline PCB 8 & 0 & 2.0606 & 0 \\
\hline PCB 28 & 0 & 0.0978 & 0 \\
\hline PCB 44 & 1.6656 & 2.0556 & 0 \\
\hline PCB 77 & 1.1008 & 0.8207 & 2.0463 \\
\hline PCB 81 & 0 & 0 & 0.0905 \\
\hline PCB 123 & 0 & 0 & 0.6878 \\
\hline PCB 153 & 0.3892 & 0 & 0.4825 \\
\hline PCB 156 & 0 & 0.9261 & 0 \\
\hline TOTAL & 3.1556 & 5.9608 & 3.3071 \\
\hline
\end{tabular}

\section{Summary Concentration of PCBs:}

The summary of total PCBs concentration in fish, parasite, water and sediment are shown in Table 10. In all the three stations, the sediment has the highest PCBs concentration, while the water has the lowest PCBs concentration, indicating that these contaminants sediment at the bottom of water while

Table 10: Total PCBs concentrations in fish, parasite, water and sediment collected in three sampling stations

\begin{tabular}{|c|c|c|c|c|}
\hline SITES & FISH $($ PPB) & PARASITE (PPB) & WATER (PPB) & SEDIMENT (PPB) \\
\hline ORIBO & 607.42 & 549.53 & 3.20 & 414.90 \\
\hline IMODE & 188.61 & 57.77 & 6.00 & 860.70 \\
\hline IKOSI & 325.43 & 569.95 & 3.30 & 405.50 \\
\hline TOTAL & 1121.46 & 1177.25 & 12.50 & 1681.10 \\
\hline
\end{tabular}

Bioconcentration Factor (BCF):

Table 11 shows the bioconcentration factor in the fish and parasite across stations. The Parasite had the highest concentration factor (319.88) while Synodontis clarias had a low bio- concentration of 319.88 compared to the parasite. Across the stations, Oribo (361.55) had the highest concentration followed by Ikosi (271.33) while Imode (41.07) had the least concentration. 
Table 11: Bio-concentration factor in different stations

\begin{tabular}{|l|c|c|}
\hline \multirow{2}{*}{ SITES } & \multicolumn{2}{|c|}{ BCF } \\
\cline { 2 - 3 } & FISH & PARASITE \\
\hline ORIBO & 189.82 & 171.73 \\
\hline IMODE & 31.44 & 9.63 \\
\hline IKOSI & 98.62 & 172.71 \\
\hline Total & 319.88 & 354.07 \\
\hline
\end{tabular}

Biota-Soil Accumulation Factor (BASF)

Table 12 shows the biota-soil accumulation factor in fish and parasite at the Epe axis of Lekki lagoon. The parasite had the highest accumulation factor of 2.80 while the fish had 2.42 which were slightly low compared to that of the parasite. Across the stations, Oribo (2.72) had the highest accumulation followed Ikosi (2.21) and the lest was IMODE (0.29)

Table 12: Showing biota-soil accumulation factor in different stations

\begin{tabular}{|l|r|c|}
\hline \multirow{2}{*}{ SITES } & \multicolumn{2}{|c|}{ BSAF } \\
\cline { 2 - 3 } & FISH & PARASITE \\
\hline ORIBO & 1.40 & 1.32 \\
\hline IMODE & 0.22 & 0.07 \\
\hline IKOSI & 0.80 & 1.41 \\
\hline TOTAL & 2.42 & 2.80 \\
\hline
\end{tabular}

\section{DISCUSSION}

Stress allows the hosts to be susceptible to parasitic diseases which can thereafter be transmitted from one host to another . Environmental stress is an indication of parasitic infections in fishes (Schludermann et al., 2003). The reactions of the hosts against the parasites may lead to some pathological reactions (Don-Pedro et al., 2004; Falcao et al., 2008). Helminthes parasites infections were higher in males 30 $(20.00 \%)$ than females $26(17.33 \%)$. This is similar to the report of (Allumma and Idowu, 2011; Akinsanya et al., 2008). The prevalence of $(37.5 \%)$ recorded in this study in Synodontis clarias was lower than $85.2 \%$ reported in Zaria (Ashraf, 2005).Condition factor informed of the health status of a fish population (Ighwela, et al., 2011). Length and weight parameters of the fishes were taken to relate these to parasitic infections (Sarkar et al., 2013). This findings were also made by Abowei and Davies (Abowei and Davies, 2009) (Deekae et al., 2010) where negative allometric growth was obtained $(b=0.88$ and $b=2.88$ ) for the studies of Clarotes laticeps. The differences in reports could be as a results of fishes from different geographical locations(Akinsanya, 2007). The health statusof fishes is anchored on the condition factor (Marcogliese, 2005). It is concluded that fishes with high weight are in good condition than fishes with less (Falcao et al., 2008).

In this study, the fish species were infected with two kinds of parasites the cestodes (Wenyonia spp) and nematode (Raphidascaroides spp) which is common among the family mockokidae and is in conformity with the report of Ahmed et al., (2012). Raphidascaroides is a small ovoviparous nematode that is prevalent in most African freshwater fishes, notably Siluroids.

Histopathological alterations observed is in agreement with the report of (Akinsanya, 2007).Winkaler, et al., (2001) and Tkatcheva, et al., (2004), some morphological changes in gills and intestine may represent adaptive strategies to maintaining physiological functions. The lesions observed indicates that the fishes were affected as a result of 
intake of contaminants. In this study the fish gill showed hyperplasia, epithelial lifting, fusion and loss of filaments which can result in difficulty of oxygen, carbon dioxide, acids and ammonia exchanges. The effects can also lead to hindrance in the transfer of ions and water. The intestine of Synodontis clarias showed congestion of the submucosa, degeneration of epithelia layer and debris in the lumen. These effects can hinder the digestion and absorption of food materials in the fish which might lead to loss of appetite of the fish leading to decrease in the size of fish or reduction in rate of reproduction or even mortality of the fish thereby leading to species extinction and reduction in economic value of the fish.

Parasitism coupled with pollution could either increase or decrease the prevalence, intensity and load of the parasites and upset host/parasite equilibrium which could lead to diseased condition and mortality of the host.

The PCB congeners $8,18,28,44$, $77,81,123,153,156$ detected in the water and sediment sample of all the 209 PCB congener is in line with reports from (Wania and Mackay, 1996) who stated that the concentration of volatile compound is low in tropical areas and higher in temperate or polar regions. Also, it is well known that lower chlorinated PCB can volatilize and are thus more susceptible to atmospheric removal process (Mackay et al., 1992, Fiedler 1998). The findings presented in the study, showed more of the lower chlorinated PCB congeners in the water sample than in the sediment, fish (Synodontis clarias) and parasite sample from the three stations in the Epe axis of Lekki Lagoon. Anyasi and Atagana (2013) showed that lower chlorinated PCB congeners tend to be more volatile and soluble in water, while adsorption to organic materials, sediments, and soils tends to increase with chlorination of PCB and organic content of the substrate because of their hydrophobic nature (Passatore et al., 2014).High chlorinated PCBs were also detected in Synodontis clarias and parasite samples from Epe axis of Lekki Lagoon, having relatively high amount of congeners is an indication that the water body is less contaminated as it contains the high concentration of poly chlorinated biphenyl, which is a toxic form of PCB.

The fish samples collected from Oribo had the high concentration of congeners 28, 18, 44, and 52 among other detected, while fish samples collected from Imode had high concentration of $44,18,8$ and 28 and the fish samples collected from Ikosi also had high concentration of PCB 44, 18, 8 and 123 respectively. However, the concentration of PCBs level found in the fish tissue was above W. H. O limits of 200 part per billion (ppb) in Oribo and Ikosi (607.42ppb and 325.43ppb) sampling station while the concentration was below in Imode (188.61ppb) sampling station and hence the Synodontis clarias in Oribo and Ikosi is not safe and edible for consumption. The parasite samples collected from the organs of Synodontis clarias in ORIBO was analysed and found to be high in PCB 81, 77 and 52 while parasite collected fish samples from IMODE was found to be high in PCB 18, 81 and 77 and parasite collected from fish samples in IKOSI was also analysed and found to be high in PCB 81 and 18 respectively.

The concentration of PCB congeners in the sediment from each of the three stations were also analysed and found to contain high amount of PCB 81, 77 and 8 in samples collected from Oribo, PCB 81, 77 and 123 in Imode and PCB 81, 101 and 77 in Ikosi respectively. Although the major sources of PCB contamination in the Epe axis of Lekki Lagoon is not known, the presence of PCB congeners can be linked to run-off from industrial sites around the environ. 
The results from this study demonstrates a persistent problem with polychlorinated biphenyls, leading to high risk in fish species in aquatic ecosystems, and for the human populations living near these regions, concentration of PCBs in Synodontis clarias at Epe axis of Lekki lagoon in Oribo and Ikosi is already far above the WHO limits for PCBs in fish, while is at warning limits in Imode sampling station. Biological monitoring of the water and fish meant for consumption should be done regularly. Laws passed on our aquatic environment should be obeyed. The activities at the three sampling stations (Oribo, Imode and Ikosi) should be kept under strict surveillance. However, the study showed a need for continuous pollution assessment study of aquatic organisms and its environment.

\section{REFERENCES}

Abowei, J.F.N.and Davies, O.A. (2009). Some population parameters of Clarotes laticeps from the fresh water reaches of Lower Nun River Niger Delta Nigeria. African Journal of Science Research, 1: 10-19.

Agency for Toxic Substances and Disease Registry (ATSDR). 2001. Toxicological profile for Asbestos. Atlanta, GA: U.S. Department of Health and Human Services, Public Health Service.

Ahmed, T.A. Qureshi, A.B. Singh, S. Manohar, Kamlesh. Borana, S.R. and Chalko. (2012). Effect of dietary protein, lipid and carbohydrate contents on the growth, feed efficiency and carcass composition of Cyprinus carpio communis fingerlings.International $J$. Fisheries and Aquaculture., 4 (3): 30-40.

Arkoosh, M. R., E. Casillas, P. Huffman, E. Clemons, J. Evered, J. E. Stein and
Varanasi,U. (1998). Increased susceptibility of juvenile Chinook salmon from a contaminated estuary to Vibrio anguillarum. Transactions of the American Fisheries Society. 127: 360-374.

Ashley, J.T.F., and J. E. Baker. (1999). Hydrophobic organic contaminants in surficial sediments of Baltimore Harbor: Inventories and sources. Environmental Toxicology and Chemistry. 18: 838-849.

Agency for Toxic Substances and Disease Registry (ATSDR). (2001) Toxicological profile for asbestos. Atlanta:U.S. Department of Health and Human Services, Public Health Service.

Akinsanya, B., Hassan, A.A. and Adeogun, A.O. (2008). Gastrointestinal helminth parasites of the fish Synodontis clarias from Lekki lagoon, Lagos, Nigeria. Revista de Biologia Tropical 56: 20212026.

Akinsanya, B., Otubanjo, O.A. and Ibidapo, C.A. (2007). Helminth Bioload of Chrysichthys nigrodigitatus Lacepede, 1802) from Lekki Lagoon, Lagos, Nigeria. Turkish Journal of fish Aquaculture Science, 7: 83-87.
Akinsanya
B.
(2007). Histopathological study on the parasitized visceral organs of some fishes of Lekki Lagoon, Lagos, Nigeria. Journal of Life and Science, 4(3): 70-76.

Alberto, A., Camargo, F.M., Verani, J.R., Costa, O.F.T. and Fernandes, M.N. (2003). Health variables and gill morphology in the tropical fish Astyanax fasciatus from a sewagecontaminated river. Ecotoxicology of the 
Environment and Safety, 61: 247-255.

Allumma, M.I. and Idowu, R.T. (2011). Prevalence of gills helminth of Clarias gariepinus in Baga side of Lake Chad. Journal of Applied Science and Environmental Management, 15: 47-50.

Anyakora, C.A., Ogbeche, K.A., Palmer, P. and Coker, H. (2005). Determination of Polynuclear aromatic hydrocarbos in the marine samples of Siokolo fishing settlement. $J$. Chromatography. A. 1073 (1-2): $323-330$.

Anyakora, C.A., Ogbeche, K.A, Unyimadu, J., Olayinka ,K., Alani, R. and Alo, B. (2004). Determination of Polynuclear Aromatic Hydrocarbons in the water sample of the Lagos lagoon. Nigerian Journal of Pharmaceutical. 35: 35-39.

Ashraf, W. (2005). Accumulation of heavy metals in kidney and heart tissues of Epinephelus microdon, fish from the Arabian Gulf.

Environmental

Monitoring Assessment, 101: 311-316.

Beyer, A., Wania, F., Gouin, T., Mackay, D.and Matthies, M. (2002). Selecting internally consistent physicochemical properties of organic compounds. Environmental Toxicology and Chemistry. 21: 941e-953.

Birmingham, B., A. Gilman, D. Grant, J. Salminen, M. Boddington, B. Thorpe, I. Wile, P. Tofe, and V. Armstrong (1989). PCDD/PCDF multimedia exposure analysis for the Canadian population: detailed exposure estimation. Chemosphere. 19: 637-42.
Danuta T. Z., Griffiths,R.W. and Kaushik,N.K..

(1997).

Biomagnification of polychlorinated biphenyls through a riverine food web. Environmental Toxicology and Chemistry. 17: $1463-1471$.

Deekae,S.N., Chukwu, K.O. and Awotogha, G. (2010). Lengthweight relationship and condition factor of Alectis alexandricus in Bonny River, Nigeria. Journal of Physical Activity and Health, 5(4): 16-18.

Don-Pedro, K.N, Oyewo, E.O. and Otitoloju, A.A. (2004). Trend of heavy metal concentration in Lagos Lagoon ecosystem, Nigeria. West Africa Journal of Applied Ecology, 5: 103-114.

El-Shahawi M.S., Hamza A., Bashammakh A.S., and AlSaggaf W.T. An overview on the accumulation, distribution, transformations, toxicity and analytical methods for the monitoring of persistent organic pollutants. Talanta 2010: 80: 1587-1597.

Erickson, U., Sigholt, T. and Seland, A. (1997). Handling stress and water quality during live transportation and slaughter of Atlantic salmon (Salmo salar). Aquaculture.149: 243252.

EPA (U.S. Environmental Protection Agency). (1994). Estimating Exposure to Dioxinlike Compounds, Volume II: Properties, Sources, Environmental Levels, and Background Exposures. EPA/600/6-88/005c. Office of Health and Environmental Assessment, U.S. Environmental Protection Agency, Washington, DC. June. 
EPA. (2005). Guidelines for Carcinogen Risk Assessment. 70 FR 17765-17817

Falcao, H., Lunet, N., Neves, E., Iglesias, I. and Barros, $\mathrm{H}$. (2008). Anisakis simplex as a risk factor for relapsing acute urticaria. Journal of Epidemiology of Community Health, 62: 634-637.

Fitzgerald, E.F., Brix, K.A., Deres, D.A., Hwang, S.A., Bush, B., Lambert, G., and Tarbell, A.(1996) Polychlorinated biphenyl (PCB) and dichlorodiphenyl dichloroethylene (DDE) exposure among Native American men from contaminated Great Lakes fish and wildlife. Toxicological and Industrial Health. 12: 361-368.

Fiedler, G.C.( 1998). Functional, simultaneous hermaphroditism in female-phase Lysmata amboinensis (Decapoda: Caridea: Hippolytidae). Pacific Science. 52:161-169.

Ighwela, K.A., Ahmed, A.B. and Abol-Munafi, A. B. (2011). Condition factor as an indicator of growth and feeding intensity of Nile tilapia fingerlings feed on different levels of maltose. Am-Eurasian Journal of Agriculture and Environment Science, 11(4): 559-563.

Lafferty, K.D. (2008). Ecosystem consequences of fish parasites. Journal of Fish Biology, 73: 2083-2093.

MacKenzie, K., Williams, H.H., CcVicar, A.H. and Siddal, R. (2002). Parasites as indicators of water quality and the potential use of helminth transmission in marine pollution studies. Advances in Parasitology 35: 245-255.
Mackay, D., Shiu, W. Y. and Ma, K. C. (1992). Illustrated Handbook of Physical-Chemical Properties and Environmental Fate for Organic Chemicals: Monoaromatic Hydrocarbons, Chlorobenzenes, and PCBs. Chelsea, MI, USA: Lewis.

Marcogliese, D.J. (2004). Parasites of the super organism: are they indicators of ecosystem health. International Journal of Parasitology, 35: 705-716.

Mackay, D., Shiu, W. Y., and Ma, K. C. (1992). Illustrated Handbook of Physical-Chemical Properties and Environmental Fate for Organic Chemicals: Monoaromatic Hydrocarbons, Chlorobenzenes, and PCBs. Chelsea, MI, USA: Lewis.

Oliveira Ribeiro, C.A., Vollaire, Y., Sanchez-Chardi, A. and Roche, H. (2005). Bioaccumulation and the effects of organochlorine pesticides, $\mathrm{PAH}$ and heavy metals in the Eel (Anguilla anguilla) at the Camargue Nature Reserve, France. Aquatic Toxicology. 74:53e-69.

Gelnar, M., Sebelova, S., Dusek, L., Koubkova, B., Jurajda, P.and Zahradkova, S. (1997) Biodiversity of parasites in freshwater environment in relation to pollution. Parassitologia. 39:189-200.

Mir, J.I., Sarkar, U.K., Dwivedi, A.K., Gusain, O.P., Pal, A. and Jena, J.K. (2012). Pattern of intrabasin variation in condition factor and form factor of an Indian major carp Labeo rohita, Labeo rohita in the Ganges Basin, India. European Journal of Biology and Science, 4: 126135.

Passatore, L., Rossetti, C., Juwarkard, A. A. and Massacci A. (2014). Phytoremediation 
and bioremediation of polychlorinated biphenyls (PCBs): state of knowledge and research perspectives. Journal of Hazardous Materials. 278: 189202.

Rosenberg, D. M. and Resh, V. H. (1993) Introduction to Freshwater biomonitoring and benthic macroinvertebrates. New York: Chapman \& Hall. $487 \mathrm{p}$.

Sarkar, U.K., Khan, G.E., Dabas, A., Pathak, A.K., Mir, J.I., Rebello, S.C., Pal, A. and Singh, S. P. (2013). Length weight relationship and condition factor of selected freshwater fish species found in river Ganga, Gomti and Rapti, India. Journal of Environmental Biology. 34: 951-956.

Schludermann, C., R. Konecny, S., Laimgruber, J.W., Lewis, F., Schiemer, A., Chovanec and Sures, B. (2003). Fish macroparasites as indicators of heavy metal pollution in river sites in Austria. Parasitology, 126: S61-S69.

Scaps, P., (2002). A review of the biology, ecology and potential use of the common ragworm Hediste diversicolor (O.F. Mu“ller) (Annelida: Polychaeta). Hydrobiologia . 470 203e-218.

Sures, B. Siddall, R. H. and Tarschewski, H. (1999). Parasites as accumulation indicators of heavy metal pollution.Parasitology. Today. 15: 16-21.

Sures, B. (2006) How parasitism and pollution affect the physiological homeostasis of aquatic hosts. Journal of Helminthology. 80, 151-158.

SURES B. and RADSZUWEIT, H.(2007). Pollution induced heat shock protein expression in the amphipod Gammarus roeseli is affected by larvae of Polymorphus minutus (Acanthocephala).Journal of Helminthology. 81:191-197.

Sures, B. (2001). The use of fish parasites as bioindicators of heavy metals in aquatic ecosystems. Aquatic Ecology, 35: 245-255.

Sures, B. (2004). Environmental Parasitology: Relevancy of parasites in monitoring environmental pollution. Trends in Parasitology, 20: 170-177.

Sures, B. (2008). Host parasite interactions in polluted environments. Journal of fish Biology, 73: 1-10.

Szefer, P., Rockicki, J., Frelek, K. and Malinga, M. (2008). Bioaccumulation of selected trace element in lung nematode, Pseudalius inflexus, of harbour (Phococena phococena) in a polish zone of Baltic Sea. Science of Total Environment, 220: 19-24.

Walker, C., Vestberg, M. and Schüßler, A. (2007). Nomenclatural clarify-cations in Glomeromycota. Mycological Res., 111(3): 253-255.

Wang, W.X. (2002). Interactions of trace metals and different marine food chains. Marine Ecology Progress, 243: $295-$ 309.

Wania, F., and MacKay, D. (1996). Tracking the Distribution of Persistent Organic Pollutants. Environmental Science and Technology.30:390-396.

WHO (World Health Organization). (1992). Polychlorinated Biphenyls and Terphenyls. 2nd Ed. Environmental Health Criteria 140. Geneva: World Health Organization. 
Winkaler, E.U., Silva, A.G., Galindo, H.C. and Martinez, C.B.R. (2001). Biomarcadores histologicose e fisologicos para o monitoramento da saude de peixes de ribeiroes de Londrina, Estado do Parana. Acta Sci, 23: 507-514. 